\title{
Ekstraksi Pewarna Alami Kelopak Bunga Rosella (Hisbiscus Sabdariffa) Pada Pembuatan Minuman Serbuk Instan Rosella
}

\author{
Tuatul Mahfud,M.Pd \\ Jurusan Tata Boga \\ Politeknik Negeri Balikpapan \\ Jl. Soekarno Hatta Km.8 Balikpapan \\ Email : tuatulmahfud@gmail.com
}

\begin{abstract}
Operationally, this research is aimed to find out the making of Roselle nature coloring extract and the use of it in the making of instant Roselle drink powder that could be observed from the consumer acceptance of Roselle powder taste and color.
\end{abstract}

This researched use the experimental method. Roselle nature coloring extract is made by using spray drying technique with the additional decstrin filling amounted to $10 \%, 20 \%, 30 \%$ from the solution total volume. Moreover, the making process of instant Roselle drink powder is done by adding the nature coloring extract amounted to $4 \mathrm{gr}, 6 \mathrm{gr}$ and $8 \mathrm{gr}$ for each $200 \mathrm{ml}$ instant Roselle drink powder. Sixty respondents are involved in the organoleptic test.

The result shows that the making of Roselle coloring extract with the highest water level of 9, $64 \%$ is found in the Roselle powder by adding $10 \%$ of decsrtrin filling. The lowest water level of 5, $85 \%$ is found in the roselle powder with $30 \%$ of decsrtrin filling. Meanwhile, the Roselle powder with $20 \%$ decsrtrin filling, contained 7 , $15 \%$ water level. Based on the result of the powder solubility test, the highest solubility level of 98, $26 \%$ is obtained by adding $30 \%$ decstrin filling into Roselle powder. Whilst the lowest solubility level of 91, 58\% is found in the Roselle powder with $20 \%$ decstrin filling. It could be concluded that the additional of $30 \%$ decstrin filling makes a big difference to the product Ph level compare to the additional of $10 \%$ decstrin besed on Ph level test. The result measure of soluble solid matter total shows that the highest level of soluble solid mater of 39, $5 \%$ is found in the coloring Roselle which had been added with $30 \%$ decstrin. The lowest level of soluble solid mater of 5, $85 \%$ is obtained in the Roselle powder by adding $10 \%$ of decsrtrin filling. While the 29,0 level of soluble solid mater is found in the Roselle powder with $20 \%$ decstrin filling.

It can be seen that the result of organoleptic test shows the influence of the additional Roselle nature coloring toward consumer acceptance of Roselle instant drink powder's taste and color. The consumers like most the color of Roselle drink powder with $8 \mathrm{gr}$ additional Roselle nature color. While the consumers like the taste most of Roselle drink powder with 4 gr additional Roselle nature color.

Keyword : Roselle, extraction, nature coloring, instant drink powder.

\begin{abstract}
Abstrak
Secara operasional penelitian ini bertujuan untuk mengetahui pembuatan ekstrak pewarna alami rosella serta pemanfaatannya pada pembuatan minuman serbuk instan rosella yang ditinjau dari daya terima konsumen yang meliputi aspek warna dan rasa.

Penelitian ini menggunakan metode eksperimen. Pembuatan ekstrak pewarna alami rosella dilakukan dengan teknik spray drying dengan penambahan bahan pengisi deksrtrin sebesar 10\%, 20\%, dan 30\% dari total volume larutan. Sedangkan pada pembuatan minuman serbuk instan rosella adalah dengan memberikan perlakuan berupa penambahan ekstrak pewarna alami rosella masing-masing sebesar 4 gram, 6 gram, dan 8 gram dari setiap $200 \mathrm{ml}$ pelarut minuman serbuk instan rosella dalam setiap perlakuan. Penelitian ini melibatkan 60 orang responden untuk uji organoleptik.

Hasil penelitian ini menunjukkan bahwa pembuatan ekstrak pewarna rosella dengan nilai kadar air tertinggi adalah 9,64\% yaitu pada bubuk yang menggunakan bahan pengisi dekstrin sebesar 10\%. Kadar air terendah adalah 5,85\% yaitu bubuk yang menggunakan bahan pengisi dekstrin sebesar 30\%. Sedangkan bubuk yang menggunakan bahan pengisi dekstrin 20\% memiliki kadar air 7,15\%. Berdasarkan uji kelarutan bubuk,
\end{abstract}


diperoleh nilai kelarutan tertiggi adalah 98,26\% yaitu bubuk yang menggunakan bahan pengisi dekstrin 30\%, sedangkan nilai kelarutan terendah adalah 91,58\% yaitu bubuk yang menggunakan bahan pengisi dekstrin sebesar 20\%. Berdasarkan uji nilai ph dapat disimpulkan bahwa penambahan $30 \%$ dekstrin memberikan perbedaan yang nyata pada nilai pH produk bila dibandingkan dengan penambahan 10\% dekstrin. Dari hasil pengukuran total padatan terlarut menunjukkan bahwa nilai total padatan terlarut tertinggi dimiliki oleh pewarna rosella yang diberikan perlakuan dengan penambahan dekstrin sebesar $30 \%$ yaitu 39,5. Nilai total padatan terlarut terendah dimiliki oleh pewarna yang diberikan perlakuan dengan penambahan dekstrin sebesar $10 \%$ yaitu 28,0. Sedangkan nilai total padatan terlarut pada pewarna yang menggunakan penambahan dekstrin sebesar $20 \%$ yaitu 29,0 .

Berdasarkan hasil uji organoleptik menunjukkan bahwa terdapat pengaruh pada minuman serbuk instan rosella dengan penambahan pewarna alami rosella 4 gram, 6 gram., dan 8 gram terhadap daya terima konsumen pada aspek warna dan rasa. Aspek penilaian terhadap warna yang paling disukai oleh konsumen yaitu penambahan pewarna alami rosella sebanyak 8 gram pada minuman serbuk instan rosella. Sedangkan untuk aspek rasa juga terlihat pada penambahan pewarna rosella sebanyak 4 gram yang paling disukai oleh konsumen.

Kata Kunci : Rosella, Ekstraksi, pewarna alami, minuman serbuk instan.

\section{Pendahuluan}

Penampilan suatu produk terutama produk makanan dan minuman sangat ditunjang dari segi warna. Penentuan mutu bahan pangan pada umumnya sangat tergantung pada beberapa faktor seperti cita rasa, tekstur, dan nilai gizinya, juga sifat mikrobiologis. Tetapi sebelum faktor-faktor lain dipertimbangkan, secara visual faktor warna tampil lebih dahulu dan kadang-kadang sangat menentukan (Cahyadi, 2006).

Ketika memilih makanan dan minuman, tidaklah mungkin seseorang dapat langsung menentukan pilihan hanya berdasarkan rasanya. Terkecuali bagi mereka yang memang sudah terbiasa mengkonsumsi dan mengetahui betul rasa makanan tersebut. Umumnya yang pertama kali diperhatikan saat memilih makanan atau minuman adalah penampakan visualnya, terutama warna. Tidak sedikit orang yang membeli suatu jenis makanan hanya karena melihat warnanya yang menarik. Rasa memang penting untuk menarik daya terima konsumen, tetapi seringkali ditempatkan sebagai prioritas kedua, terlebih untuk produk-produk makanan dan minuman yang tergolong baru memasuki pasaran.

Dalam pengolahan makanan, biasanya digunakan pewarna untuk memberikan daya tarik tersendiri, sehingga mempunyai nilai ekonomi yang lebih tinggi dan merupakan nilai tambah dalam hal pemasaran bagi produk tersebut. Pada umumnya warna merupakan faktor yang pertama kali menjadi pertimbangan konsumen dalam menilai suatu makanan dan baik buruknya kriteria suatu makanan sangat dipengaruhi oleh warna.

Dalam hal ini, kelopak bunga rosella (Hisbiscus sabdariffa) dapat dijadikan pewarna alami dalam pengolahan minuman serbuk instant, adapun warna yang dihasilkan adalah warna merah. Warna merah pada kelopak bunga rosella dihasilkan dari pigmen antosianin dengan jenis pelargonidin (Hidayat, 2006). Selain itu Herti Maryani dan Lusi Kristiana menyebutkan hal yang sama dalam bukunya dengan judul Khasiat dan Manfaat Rosella. Antosianin termasuk pigmen warna paling umum pada tumbuhan tingkat tinggi, juga memiliki aktivitas antioksidan. Menurut Madhavi antosianin juga mampu menghentikan reaksi radikal bebas dengan menyumbangkan hidrogen atau elektron pada radikal bebas dan menstabilkannya. Menurut Francis dan Markakis, hal tersebut dikarenakan terdapatnya 2 cincin benzena yang dihubungkan dengan 3 atom $\mathrm{C}$ dan dirapatkan oleh 1 atom $\mathrm{O}$ sehingga terbentuk cincin diantara 2 cincin benzena pada antosianin (Francis, 1985). 
Penelitian tentang pigmen kelopak bunga rosella sebagai pewarna alami bertekstur bubuk sampai saat ini belum dilakukan, untuk itu maka pada penelitian ini penulis akan mencoba mengekstraksi pigmen antosianin dari kelopak bunga rosella dengan tujuan dapat dimanfaatkan sebagai pewarna alami dengan tekstur bubuk. Hal inilah yang menjadi pertimbangan dalam penelitian ini yaitu menjadikan bunga rosella sebagai pewarna alami yang aman dan tidak membahayakan kesehatan (tidak ada kecenderungan bersifat karsinogenik). Hasil yang diharapkan dari penelitian ini yaitu pewarna alami yang memiliki tekstur bubuk. Untuk menjaga kestabilan dari pigmen antosianin maka harus diperangkap dalam bahan pengisi sehingga pigmen antosianin dapat terlindungi dari udara dan cahaya. Adapun pemilihan bahan pengisi (filler) yang digunakan adalah dekstrin.

Dalam aplikasinya, pewarna kelopak rosella akan digunakan dalam pembuatan minuman serbuk instan rosella. Minuman serbuk instan yang telah beredar di pasaran Indonesia banyak sekali yang menggunakan pewarna sintetis, padahal banyak kerugian yang ditimbulkannya. Oleh karenanya, untuk meningkatkan kualitas minuman serbuk instan maka dalam hal ini minuman serbuk instan rosella dapat ditambahkan pewarna rosella yang berfungsi sebagai zat warna sekaligus sebagai antioksidan. Karena warna yang dihasilkan adalah merah cerah dan rasa yang dimiliki pewarna rosella ini adalah masam, maka pewarna ini cocok sekali bila diaplikasikan pada minuman serbuk instan.

Tujuan penelitian ini adalah untuk mengetahui proses ekstraksi pewarna alami dari kelopak bunga rosella (Hisbiscus sabdariffa) dan untuk mendapatkan informasi secara empirik tentang pemanfaatan pewarna rosella terhadap kualitas minuman serbuk instan rosella. Kualitas yang dimaksud adalah kualitas organoleptik yang meliputi aspek warna dan rasa yang dianalisa berdasarkan kesukaan konsumen.

\section{Metode Penelitian}

Metode yang digunakan dalam penelitian ini adalah metode eksperimen. Penelitian pendahuluan berupa cara ekstraksi kelopak rosella yang menggunakan jenis pelarut air (aquades) yang telah diasamkan dengan asam sitrat sebanyak $5 \%$ dari jumlah pelarut. Ekstrak yang diperoleh disaring dengan kain vlanel, Kemudian fitrat yang diperoleh dicampur dengan bahan pengisi dekstrin sebanyak 10\%, 20\%, dan 30\% dari jumlah fitrat. Campuran tersebut dikeringkan dengan alat pengering semprot (Spry Dryer) dengan inlet temperature $177^{\circ} \mathrm{C}$ dan outlet temperature $94^{\circ} \mathrm{C}$. Penelitian lanjutan berupa analisa laboratorium dari bubuk yang diperoleh yang meliputi uji kadar air, uji kelarutan bubuk, uji warna, uji $\mathrm{pH}$, dan uji total padatan terlarut. Uji organoleptik menggunakan uji hedonik untuk mengetahui daya terima konsumen terhadap pemanfaatan pewarna alami rosella dalam pembuatan minuman serbuk instan rosella, dengan penambahan pewarna rosella sebesar $4 \mathrm{gr}, 6$ gr, dan 8 gr dari setiap $200 \mathrm{ml}$ larutan minuman serbuk instan rosella. Beberapa aspek organoleptik yang diamati adalah warna dan rasa. Penelitian ini juga menggunakan metode studi kepustakaan untuk memperoleh informasi teoritis.

\section{Hasil dan Pembahasan}

Pemilihan jenis pelarut dilakukan dengan melihat derajat kepolarannya. Untuk mendapatkan pemgekstrak yang baik diperlukan pelarut yang memiliki polaritas yang sama dengan senyawa yang akan diekstrak karena senyawa polar hanya larut dengan baik dalam pelarut yang polar begitu pula senyawa non polar dapat larut dengan baik pada pelarut non polar. Derajat kepolaran suatu senyawa ditentukan oleh tetapan dielektriknya dimana senyawa yang memiliki konstanta dielektrik yang tinggi akan memiliki polaritas yang lebih tinggi. Dalam proses ekstraksi ini jenis pelarut yang digunakan adalah pelarut air, hal ini dikarenakan pigmen antosianin pada kelopak 
bunga rosella merupakan senyawa yang larut dalam pelarut yang polar seperti air, etanol, dan metanol. Dalam hal ini pelarut air memiliki polaritas yang lebih tinggi dibandingkan dengan pelarut etanol maupun metanol Senyawa flavanoid dalam kelopak bunga rosella memiliki sifat sangat larut dalam air sehingga dengan terikatnya unsur ini pada molekul pigmen antosianin menyebabkan sifat kepolaran pigmen antosianin menjadi bertambah.

Dalam proses ekstraksi, kelopak bunga rosella dihaluskan dengan menggunakan blender dan diekstraksi dengan pelarut air yang telah ditambahkan dengan asam sitrat. Lalu didiamkan dalam suhu kamar sampai didapatkan nilai konstanta warna yang tinggi yaitu selama 24 jam. Untuk menjaga kestabilan dari pigmen antosianin maka harus diperangkap dalam bahan pengisi sehingga pigmen antosianin dapat terlindungi dari udara dan cahaya, dengan penambahan bahan pengisi masing-masing sebesar 10\%, 20\%, dan 30\% dari jumlah fitrat. Dalam pemilihan bahan pengisi harus dipilih jenis bahan pengisi yang memiliki sifat yang sama dengan pelarutnya yaitu larut dalam air, dalam hal ini dekstrin merupakan bahan pengisi yang larut dalam air.

Dari hasil ekstraksi pewarna rosella dengan penambahan bahan pengisi dekstrin masing-masing sebesar 10\%, 20\%, dan 30\% dari jumlah fitrat akan dilakukan uji laboratorium untuk menentukan kadar air, kelarutan bubuk, nilai warna, nilai $\mathrm{pH}$, dan nilai total padatan terlarut.

\section{Uji Kadar Air}

Hasil penelitian terhadap kadar air menunjukkan kadar air tertinggi adalah 9,64\% yaitu pada bubuk yang menggunakan bahan pengisi dekstrin sebesar $10 \%$. Kadar air terendah adalah $5,85 \%$ yaitu bubuk yang menggunakan bahan pengisi dekstrin sebesar $30 \%$. Sedangkan bubuk yang menggunakan bahan pengisi dekstrin $20 \%$ memiliki kadar air $7,15 \%$.
Berdasarkan uji statistik terdapat pengaruh penambahan bahan pengisi dekstrin terhadap nilai kadar air pewarna rosella. Hal ini dibuktikan dengan uji RAL yaitu $F_{\text {hitung }}>$ $\mathrm{F}_{\text {tabel }}$ dimana $\mathrm{F}_{\text {hitung }}=74$ dan $\mathrm{F}_{\text {tabel }}=9,55$. Dengan demikian $\mathrm{H}_{\mathrm{o}}$ ditolak, artinya terdapat pengaruh penambahan bahan pengisi dekstrin terhadap nilai kadar air pewarna rosella. Kemudian dilanjutkan dengan uji Tukey's dengan kesimpulan semua perlakuan berbeda nyata.

\section{Kelarutan}

Berdasarkan uji kelarutan bubuk, diperoleh nilai kelarutan tertiggi adalah $98,26 \%$ yaitu bubuk yang menggunakan bahan pengisi dekstrin $30 \%$, sedangkan nilai kelarutan terendah adalah $91,58 \%$ yaitu bubuk yang menggunakan bahan pengisi dekstrin sebesar $20 \%$. Perbedaan ini disebabkan oleh perbedaan kadar air dari setiap perlakuan, dimana kadar air bubuk yang menggunakan penambahan bahan pengisi dekstrin sebesar $30 \%$ memiliki nilai kadar air yang lebih rendah dibandingkan dengan yang lainnya. Masters (1979) mengatakan bahwa pada produk yang berbentuk tepung konsentrat (instant) semakin tinggi kadar air produk, semakin sulit produk dilarutkan dalam air karena produk cenderung membentuk butiran yang lebih besar tetapi tidak porous.

Hasil uji statistik menunjukkan bahwa perbedaan konsentrasi bahan pengisi memberikan nilai kelarutan yang berbeda nyata. Hal ini dibuktikan dengan uji RAL yaitu $F_{\text {hitung }}>F_{\text {tabel }}$ dimana $F_{\text {hitung }}=1147,5$ dan $\mathrm{F}_{\text {tabel }}=9,55$. Dengan demikian $\mathrm{H}_{\mathrm{o}}$ ditolak, artinya terdapat pengaruh penambahan bahan pengisi dekstrin terhadap nilai kelarutan bubuk pewarna rosella. Kemudian dilanjutkan dengan uji Tukey's. Berdasarkan hasil uji Tukey's terlihat bahwa 1 dari 3 perlakuan penambahan bahan pengisi dekstrin pada pewarna rosella terhadap nilai kelarutan bubuk pewarna rosella menunjukkan perbedaan yang nyata. Sedangkan pada perlakuan A dan C tidak berbeda nyata, hal ini 
pun terjadi pada perlakuan $\mathrm{B}$ dan $\mathrm{C}$ tidak terlihat berbeda nyata.

\section{Uji Warna}

Nilai warna yang diukur pada produk pewarna rosella menggunakan sistem notasi Hunter yang diukur dengan alat chromameter CR-310. sistem notasi Hunter dicirikan dengan tiga parameter yaitu $L$, a, dan $b$. Notasi L menyatakan parameter kecerahan (light) yang mempunyai nilai 0 (hitam) sampai 100 (putih). Nilai L menyatakan cahaya pantul yang menghasilkan warna akromatik putih, abu-abu dan hitam. Nilai a menyatakan warna kromatik campuran merahhijau dengan nilai +a (positif) dari 0 sampai 100 untuk warna merah dan nilai -a (negatif) dari 0 sampai -80 untuk warna hijau. Notasi b menyatakan warna kromatik campuran birukuning dengan nilai $+b$ (positif) dari 0 sampai 70 untuk warna biru dan nilai -b (negatif) dari 0 sampai -70 untuk warna kuning.

Nilai L tertinggi terdapat pada bubuk yang menggunakan bahan pengisi dekstrin sebesar $30 \%$ yaitu 57,1256. Nilai L terkecil terdapat pada bubuk yang menggunakan penambahan bahan pengisi dekstrin sebesar $10 \%$ yaitu 28,9367 .

Berdasarkan uji statistik terlihat bahwa $F_{\text {hitung }}<F_{\text {tabel }}$ dimana $F_{\text {hitung }}=-7120,33$ dan $\mathrm{F}_{\text {tabel }}=5,14$. Dengan demikian $\mathrm{H}_{\mathrm{o}}$ diterima, artinya tidak terdapat pengaruh penambahan bahan pengisi dekstrin dengan konsentrasi yang berbeda terhadap nilai L (kecerahan) pewarna rosella.

Bubuk yang menggunakan penambahan bahan pengisi dekstrin sebesar $20 \%$ memiliki nilai a tertinggi yaitu 33,4242, sedangkan nilai a terendah terdapat pada bubuk yang menggunakan bahan pengisi dekstrin sebesar $10 \%$ yaitu 22,4912 .

Berdasarkan uji statistik terlihat bahwa $F_{\text {hitung }}>F_{\text {tabel }}$ dimana $F_{\text {hitung }}=31,72$ dan $F_{\text {tabel }}$ $=5,14$. Dengan demikian $\mathrm{H}_{\mathrm{o}}$ ditolak, artinya terdapat pengaruh penambahan bahan pengisi dekstrin dengan konsentrasi yang berbeda terhadap nilai a pewarna rosella. Kemudian dilanjutkan dengan uji Tukey's, Berdasarkan hasil uji tersebut terlihat bahwa 1 dari 3 perlakuan penambahan bahan pengisi dekstrin pada pewarna rosella terhadap nilai a bubuk pewarna rosella menunjukkan perbedaan yang nyata yaitu pada perlakuan $B$ dan C. Sedangkan pada perlakuan A dan B tidak berbeda nyata, hal ini pun terjadi pada perlakuan A dan $\mathrm{C}$ tidak terlihat berbeda nyata.

Hasil pengukuran terhadap nilai $b$ bubuk pewarna rosella menunjukkan bahwa nilai $b$ yang tertinggi terdapat pada bubuk yang menggunakan penambahan bahan pengisi dekstrin $20 \%$ yaitu 8,2258 . Sedangkan nilai $\mathrm{b}$ terkecil terdapat pada bubuk yang menggunakan bahan pengisi dekstrin 30\% yaitu 4,2661 .

Berdasarkan uji statistik terlihat bahwa $F_{\text {hitung }}>F_{\text {tabel }}$ dimana $F_{\text {hitung }}=6970,59$ dan $\mathrm{F}_{\text {tabel }}=5,14$. Dengan demikian $\mathrm{H}_{\mathrm{o}}$ ditolak, artinya terdapat pengaruh penambahan bahan pengisi dekstrin terhadap nilai $b$ pewarna rosella. Kemudian dilanjutkan dengan uji Tukey's, Berdasarkan hasil uji tersebut terlihat bahwa 2 dari 3 perlakuan penambahan bahan pengisi dekstrin pada pewarna rosella terhadap nilai $\mathrm{b}$ bubuk pewarna rosella menunjukkan perbedaan yang nyata yaitu pada perlakuan $\mathrm{A}$ dan $\mathrm{C}$, dan $\mathrm{B}$ dan $\mathrm{C}$. Sedangkan pada perlakuan A dan B tidak berbeda nyata.

\section{UJI pH}

Dari hasil pengukuran $\mathrm{pH}$ dengan menggunakan pHmeter menunjukkan bahwa nilai $\mathrm{pH}$ tertinggi terdapat pada pewarna dengan penambahan konsentrasi bahan pengisi sebesar $30 \%$ bila dibandingkan dengan penambahan konsentrasi bahan pengisi sebesar $20 \%$ maupun $10 \%$. Peningkatan penambahan dekstrin akan cenderung menaikkan $\mathrm{pH}$ produk.

Berdasarkan hasil uji statistik terlihat bahwa tidak terdapat pengaruh penambahan bahan pengisi dekstrin terhadap nilai kadar $\mathrm{pH}$ pewarna rosella. Hal ini dibuktikan dengan uji RAL yaitu $F_{\text {hitung }}<F_{\text {tabel }}$ dimana $F_{\text {hitung }}=9$ dan $\mathrm{F}_{\text {tabel }}=9,55$. Dengan demikian $\mathrm{H}_{\mathrm{o}}$ diterima, 
artinya tidak terdapat pengaruh penambahan bahan pengisi dekstrin terhadap nilai kadar $\mathrm{pH}$ pewarna rosella.

\section{Uji Total Padatan Terlarut}

Dari hasil pengukuran total padatan terlarut dengan menggunakan refraktometer menunjukkan bahwa nilai total padatan terlarut tertinggi dimiliki oleh pewarna rosella yang diberikan perlakuan dengan penambahan dekstrin sebesar 30\% yaitu 39,5. Nilai total padatan terlarut terendah dimiliki oleh pewarna yang diberikan perlakuan dengan penambahan dekstrin sebesar $10 \%$ yaitu 28,0 . Sedangkan nilai total padatan terlarut pada pewarna yang menggunakan penambahan dekstrin sebesar $20 \%$ yaitu 29,0 .

Untuk mendapatkan pewarna yang baik maka pewarna tersebut harus memiliki nilai kelarutan dan total padatan terlarut yang tinggi, sehingga mudah dilarutkan dalam pelarut air. Dari hasil analisa laboratorium terhadap kualitas pewarna rosella didapatkan bahwa nilai kelarutan dan total padatan terlarut tertinggi terdapat pada formulasi dengan penambahan bahan pengisi dekstrin sebesar 30\% dari jumlah fitrat.

Setelah itu pewarna rosella dengan penambahan bahan pengisi dekstrin sebesar $30 \%$ akan diuji organoleptik pada pemanfaatannya dalam pembuatan minuman serbuk instan rosella, adapun aspek yang diuji meliputi aspek warna dan rasa.

\section{Uji Organoleptik}

Hasil penelitian eksperimen diperoleh data uji organoleptik yang dinilai oleh 60 orang panelis mahasiswa Tata Boga yang telah mengikuti mata kuliah pada Kelompok Bidang Ilmu (KBI) Pengelolaan Makanan. Data yang didapat merupakan data hasil pembuatan minuman serbuk instan rosella dengan tiga perlakuan yang berbeda dengan penambahan pewarna alami rosella sebesar 4 gram, 6 gram dan 8 gram dari setiap $200 \mathrm{ml}$ pelarut minuman serbuk instan rosella.

\section{Aspek Warna}

Dari data aspek warna minuman serbuk instan rosella diatas dapat dilihat bahwa pada minuman serbuk instan rosella yang mendapat penambahan pewarna rosella sebanyak 4 gram dari $200 \mathrm{ml}$ pelarut memiliki nilai modus 3 berarti untuk warna tersebut para panelis menilai agak merah. Untuk minuman serbuk instan rosella dengan penambahan pewarna rosella sebesar 6 gram memiliki nilai modus 4 berarti panelis menilai minuman tersebut memiliki warna merah. Sedangkan pada penambahan pewarna rosella sebesar 8 gram memiliki nilai modus 5 berarti panelis menilai minuman tersebut memiliki warna merah pekat. Dari nilai rata-rata maka dapat ditarik kesimpulan bahwa rata-rata warna yang disukai oleh panelis adalah warna yang memiliki warna merah tua $(4,63)$ yaitu pada minuman yang diberi perlakuan dengan penambahan pewarna rosella sebesar 8 gram dari $200 \mathrm{ml}$ pelarut.

\section{Aspek Rasa}

Dari data aspek rasa minuman serbuk instan rosella diatas dapat dilihat bahwa pada minuman serbuk instan rosella yang mendapat penambahan pewarna rosella sebanyak 4 gram dari $200 \mathrm{ml}$ pelarut memiliki nilai modus 5 berarti untuk rasa tersebut para panelis menilai rasa manis sedikit manis. Untuk minuman serbuk instan rosella dengan penambahan pewarna rosella sebesar 6 gram memiliki nilai modus 4 berarti panelis menilai minuman tersebut memiliki rasa manis asam. Sedangkan pada penambahan pewarna rosella sebesar 8 gram memiliki nilai modus 1 berarti panelis menilai minuman tersebut memiliki rasa sangat asam. Dari nilai rata-rata maka dapat ditarik kesimpulan bahwa rata-rata rasa yang disukai oleh panelis adalah minuman serbuk instan rosella dengan penambahan pewarna rosella sebesar 4 gram yaitu dengan rasa manis sedikit asam $(4,2)$. 


\section{Kesimpulan}

- Dari hasil analisa laboratorium terhadap kualitas pewarna rosella didapatkan bahwa nilai kadar air, nilai kecerahan, nilai $\mathrm{Ph}$, kelarutan dan total padatan terlarut tertinggi terdapat pada formulasi dengan penambahan bahan pengisi dekstrin sebesar 30\% dari jumlah fitrat.

- Berdasarkan hasil uji organoleptik menunjukkan bahwa terdapat pengaruh pada minuman serbuk instan rosella dengan penambahan pewarna alami rosella 4 gram, 6 gram., dan 8 gram terhadap daya terima konsumen pada aspek rasa dan warna.

- Aspek penilaian terhadap rasa yang paling disukai oleh konsumen yaitu penambahan pewarna alami rosella sebanyak 4 gram pada minutan serbuk instan rosella. Sedangkan untuk aspek warna juga terlihat pada penambahan pewarna rosella sebanyak 8 gram yang paling disukai oleh konsumen.

\section{Ucapan Terima kasih}

Ucapan terimakasih ditujukan kepada pihak Laboratorium Teknologi Pangan IPB dan UNJ yang telah menyediakan tempat untuk uji lab dari penilitian ini.

\section{Daftar Pustaka}

Buchle, K.A., et.al, 1987, "Ilmu Pangan", diterjemahkan oleh: Hari Purnomo dan Adiono, UI Press, Jakarta.

Cahyadi, Wisnu, 2006, "Analisa dan Aspek Kesehatan Bahan Tambahan Pangan", Bumi Aksara, Jakarta.

Cook, T.M, D.J Cullen, 1986, "Industri Kimia Operasi Aspek-aspek Keamanan dan Kesehatan”, Erlangga, Jakarta.

Fachrudin, Lisdiana, 1998, "Memilih dan Memanfaatkan Bahan Makanan Tambahan”, Trubus Agriwidya, Jakarta.
Glicksman, Martin, 1980, "Food Hydrocolloids Volume I", CRC Press, Florida.

Hidayat, Nur, Elfi, Anis S., 2006, "Membuat Pewarna Alami", Trubus Agrisarana, Surabaya.

MacDaougall, Douglas B., 2002, "Colouring in Food, Improving Quality", CRC Press, New York.

Maryani, Herti, dkk., 2005, "Khasiat dan Manfaat Rosella", Agro Media Pustaka, Jakarta.

M deMan, John, 1997, ”Kimia Makanan edisi kedua", ITB Bandung, Bandung.

M.S, Sakidja, 1989, "Kimia Pangan", Depdikbud, Jakarta.

Noor, Zuheid, 1994, "Penganeka ragaman Makanan Tradisional Melalui Mutu", Media Komunikasi Dan Informasi Pangan : vol V.

Poerwardarminta, W.J.S, 2002, "Kamus Umum Bahasa Indonesia", Balai Pustaka, Jakarta.

Suhardjito, Y.B., 2005, "Pastry dalam Perhotelan", Andi, Yogyakarta.

Tjahjadi, Carmen, 1987, "Pewarna Makanan", Fakultas Pertanian Universitas Padjajaran, Bandung.

T. Soekarto, Soewarno, 1981, "Penilaian Organoleptik", Pusat pengembangan Teknologi Pangan IPB, Bogor. 1985, "Penelitian Organoleptik Untuk Industri Pangan dan Hasil Pertanian”, Bhratara Karya Aksara, Jakarta.

Winarno, F.G, 1997, "Kimia Pangan dan Gizi”, Gramedia, Jakarta.

Teknologi Pangan”, Gramedia, Jakarta. 